\title{
The Effect of Hurricane Katrina on the Labor Market Outcomes of Evacuees*
}

\author{
Jeffrey A. Groen \\ Bureau of Labor Statistics \\ Groen.Jeffrey@bls.gov
}

\author{
Anne E. Polivka \\ Bureau of Labor Statistics \\ Polivka.Anne@bls.gov
}

December 21, 2007

\begin{abstract}
We use data from the Current Population Survey collected both before and after Hurricane Katrina to estimate the impact of Katrina on the labor market outcomes of evacuees. Our estimates are based on a difference-in-differences strategy that compares evacuees to residents of Katrina-affected areas prior to Katrina, with non-evacuees and residents of areas that were unaffected by Katrina as a control group. We estimate that Katrina had substantial effects on the labor market outcomes of evacuees over the 13-month period immediately following Katrina. However, our estimates suggest that the effects of Katrina diminished substantially over time as evacuees recovered from the hurricane and adjusted to new economic and social conditions. Evacuees who did not return to their pre-Katrina areas have fared much worse in the labor market than have those who returned. Differences in individual and family characteristics account for some of the differences in outcomes between returnees and non-returnees. However, we present evidence that non-returnees have fared much worse in the labor market primarily because they came from areas that experienced greater housing damage due to the storm and thus were more likely to be displaced from their jobs.
\end{abstract}

\footnotetext{
${ }^{*}$ We are grateful to seminar participants at the Bureau of Labor Statistics, the Society of Labor Economists meetings, and the Southern Economic Association meetings for useful comments. The views expressed in this paper are solely those of the authors and do not reflect the views of the Bureau of Labor Statistics.
} 


\section{Introduction}

Hurricane Katrina, which struck the Gulf Coast in August 2005, was one of the largest and most deadly storms in U.S. history. The massive cyclone generated a storm surge as high as 27 feet, which caused catastrophic flooding in the city of New Orleans and devastating damage along the Gulf coasts of Alabama, Mississippi, and Louisiana. As a result, Katrina caused a large relocation of people and created a large amount of job displacement. The number of mass layoff events in Louisiana and Mississippi rose sharply in September 2005 following Katrina (Sharon P. Brown and Patrick Carey 2006). In the two months following Katrina, payroll employment declined by 35 percent in the New Orleans metropolitan area and declined by 10 percent in the entire state of Louisiana (U.S. Bureau of Labor Statistics 2006).

The literature on job displacement suggests that evacuees who were separated from their jobs would experience a period of unemployment and, even after finding a new job, long-term earnings losses (e.g., Lori G. Kletzer 1998). In addition to being displaced from their jobs, many evacuees were also displaced from their homes and had to relocate to new areas. This physical dislocation may have forced many evacuees to establish new social networks and enter unfamiliar labor markets. Many of those who returned to their pre-Katrina areas had to deal with extensive damage to their homes and to public infrastructure (e.g., roads, transit systems, schools). As a result, evacuees may have faced higher costs of searching for a new job than is typical for displaced workers. ${ }^{1}$ Furthermore, the hurricane and/or the evacuation may have had direct effects on the physical and emotional health and general well-being of evacuees.

\footnotetext{
${ }^{1}$ However, many employers in several cities where evacuees relocated made special efforts to hire evacuees (Ilan Brat and Janet Adamy, “Job Outpouring for Evacuees Sparks Backlash,” Wall Street Journal, September 13, 2005, p. B1).
} 
In this paper, we estimate the impact of Katrina on the labor market outcomes of evacuees. We also compare the labor market outcomes of evacuees who returned to their preKatrina areas with those of evacuees who have not returned.

\section{Data and Descriptive Statistics}

Our analysis is based on data from the Current Population Survey (CPS), a nationally representative, monthly survey of approximately 60,000 occupied housing units. The CPS was modified in the wake of Hurricane Katrina to include special questions that identify evacuees, the county (or parish) from which they had evacuated, and if and when these individuals returned to their pre-Katrina residences (Lawrence S. Cahoon et al. 2006). We use the responses to these questions, which were part of the CPS from October 2005 to October 2006, in combination with demographic and labor force information collected in the CPS on a regular basis. Labor force information is collected in the CPS from persons age 16 and older; the estimates reported in this paper correspond to this age range.

We classify as an evacuee anyone who was identified as an evacuee in any of the months that his household was interviewed. In addition, to more carefully focus our analysis on those directly affected by Hurricane Katrina we require that prior to the hurricane evacuees lived in Louisiana, Mississippi, or Alabama in a county designated by the Federal Emergency Management Agency (FEMA) as eligible for both public and individual disaster assistance as a result of damages due to Hurricane Katrina. (For details on this definition of evacuees, see Groen and Polivka 2007.) 
We use CPS data from September 2004 to August 2005 to account for pre-Katrina differences between areas that were affected by Katrina and those that were unaffected. ${ }^{2}$ We define affected areas as counties designated by FEMA as eligible for both public and individual disaster assistance for Katrina; unaffected areas are the rest of the United States. Our pre-Katrina data contain 22,124 monthly observations covering 6,883 individuals in affected areas and $1,255,409$ monthly observations covering 393,438 individuals in unaffected areas. The postKatrina data contain 6,550 monthly observations on 2,033 evacuees and 1,366,831 monthly observations on 411,778 non-evacuees (individuals living anywhere in the United States and not classified as evacuees). ${ }^{3}$

As explained in an earlier paper (Groen and Polivka 2007), the estimates we derive from the CPS indicate that approximately 1.5 million individuals age 16 and older evacuated from their homes, even temporarily, because of Hurricane Katrina. We estimate that 75 percent of evacuees were living in Louisiana prior to the storm, 19 percent were living in Mississippi, and 6 percent were living in Alabama. The evacuation was widespread: the demographic composition of evacuees, according to the CPS data, closely mirrors the composition of those residing in the Katrina-affected counties in these states prior to the storm. By contrast, prior to the storm the demographic composition of the region affected by Katrina was quite different from the composition of the remainder of the U.S.; in particular, the Katrina-affected region had a significantly larger proportion of its residents who were black and a larger proportion of its residents with relatively low levels of education.

\footnotetext{
${ }^{2}$ The August 2005 CPS interviews were conducted from August 14 (Sunday) through August 22 (Tuesday), which was prior to the mandatory evacuations of Gulf Coast areas that were ordered on August 27 and August 28 and prior to Katrina making landfall in New Orleans on August 29.

${ }^{3}$ Given the months we selected to generate pre-Katrina estimates, the time period when the Katrina questions were included in the CPS, and the interview schedule for CPS households (see footnote 6), the maximum number of monthly observations for individuals in our sample is four in the pre-Katrina period and five in the post-Katrina period. In the regression estimates, we adjust the standard errors to account for multiple observations per individual.
} 
On average over the entire post-Katrina period covered by our CPS data, the labor market outcomes of evacuees were substantially worse than the outcomes of non-evacuees (Table 1). For example, the employment-population ratio was 11.4 percentage points lower for evacuees and the unemployment rate was 7.4 percentage points higher for evacuees. Reflecting the decrease in employment, an examination of all individuals (workers and non-workers) indicates that evacuees on average worked about 4 fewer hours per week than non-evacuees and earned approximately $\$ 120$ less per week. Among just those who were employed after the storm, evacuees worked slightly more hours per week on average than did non-evacuees but had lower earnings. ${ }^{4}$

Among evacuees, we distinguish between returnees and non-returnees. In this paper we define returnees as evacuees who were living in the same county at the time of the post-storm CPS interview as they did prior to Katrina; non-returnees are evacuees who were living in different counties. Over the 13-month period covered by the CPS data on evacuees, we estimate that 73 percent of evacuees returned to their pre-Katrina county. ${ }^{5}$ Non-returnees were doing substantially worse than returnees in the labor market (Table 1). Notably, the unemployment rate for non-returnees was 30.6 percent compared to 6.0 percent for returnees. Among those individuals who worked after the storm, returnees and non-returnees are similar in terms of average hours and earnings.

\section{The Effect of Hurricane Katrina on Evacuees}

The challenge to estimating the effect of Katrina on the labor market outcomes of evacuees is the lack of information on what the outcomes for evacuees would have been in the

\footnotetext{
${ }_{5}^{4}$ Earnings data are collected monthly in the CPS from approximately one-fourth of the sample.

${ }^{5}$ By contrast, 65 percent of evacuees returned to their pre-Katrina residence. We define returning based on county in this paper because those who changed residences within county are likely to face similar labor market opportunities as if they had returned to their pre-Katrina residence.
} 
absence of the storm. Since the CPS sample is based on addresses and the monthly survey is designed as a short panel and collects a limited amount of longitudinal information, we do not know what most of the evacuees in our sample were doing prior to the storm. ${ }^{6}$ However, we do know what residents of the Katrina-affected areas were doing prior to Katrina, using pre-Katrina CPS data. Our strategy is to compare evacuees to residents of Katrina-affected areas prior to Katrina; these groups are very similar in terms of observable characteristics (Appendix Table 1). We use non-evacuees and pre-Katrina residents of areas that were unaffected by Katrina to control for economy-wide changes in the labor market from the pre-Katrina to post-Katrina time periods. $^{7}$

Formally, we implement this difference-in-differences strategy using regressions of the form:

$$
\left.Y_{i t}=\alpha_{t}+\theta X_{i t}+\beta_{1} \text { Treat }_{i t}+\beta_{2} \text { Treat }_{i t} \times \text { Post }_{i t}\right)+\varepsilon_{i t},
$$

where $Y_{i t}$ indicates an employment outcome of individual $i$ in month $t^{8}$ The variable Treat ${ }_{i t}$ is an indicator for observations in the "treatment" group (evacuees and residents of affected areas in the pre-Katrina period). Time effects are represented by $\alpha_{t}$, which is a month-specific fixed

\footnotetext{
${ }^{6}$ The CPS uses a 4-8-4 sample design in which an address is scheduled to be interviewed for four consecutive months, not interviewed for the subsequent eight consecutive months, and then interviewed again for the subsequent four consecutive months. Each calendar month a new group of residential addresses starts this rotation pattern. No attempts are made to interview individuals or households that move away from an address. Given this rotation pattern and the fact that the CPS is address-based, pre-storm labor market information that can be obtained by matching individuals before and after the storm is available for only a subset of evacuees who returned to their prior addresses and is completely absent for individuals who did not return to their previous addresses (even if they returned to their pre-storm counties). The CPS collects only limited longitudinal information which does not typically include calendar dates for starting and stopping times of events.

${ }^{7}$ This strategy is similar to the approach taken by Jacob L. Vigdor (2007).

${ }^{8}$ The basic results in this section are robust to a number of modifications of equation (1), including (a) replacing the month fixed effects with a constant term and an indicator for the post-Katrina period, (b) allowing $\theta$ to be different for treatment and control observations, and (c) using a logit model rather than a linear model in cases where the dependent variable is a dummy variable. The results are also robust to defining the control group using the five states adjacent to the three states directly affected by Katrina.
} 
effect, and Post ${ }_{i t}$, which indicates observations in the post-Katrina time period. ${ }^{9}$ The coefficient $\beta_{2}$ measures the impact of Katrina on the labor market outcomes of evacuees. $X_{i t}$ is a vector of individual and family characteristics: age, race, Hispanic ethnicity, gender, educational attainment, marital status, number of children, and indicators for living in an MSA, having ever served on active duty in the U.S. Armed Forces, and being born outside the United States. ${ }^{10}$

Estimates of Katrina effects with and without the controls for individual and family characteristics are shown in columns (2) and (3) of Table 2. A comparison of these estimates indicates that controlling for individual and family characteristics has relatively little impact on the estimated effect of Katrina on the various labor market outcomes of evacuees. When individual and family controls are included it is estimated that Katrina lowered the labor force participation rate of evacuees by about 3.5 percentage points, lowered the employmentpopulation ratio by about 7.1 percentage points, and raised the unemployment rate by about 6.3 percentage points. $^{11}$

We examine how the Katrina effect varies over the post-Katrina time period by defining a linear time trend Time $_{t}$ that is 0 for the first month of the post-Katrina period (October 2005), 1 for the second month, and so on until 12 for the last month (October 2006). We modify equation (1) by including among the explanatory variables an interaction between the time trend and the Treat $_{i t} \times$ Post $_{i t}$ variable. The coefficient on the additional interaction term,

\footnotetext{
${ }^{9}$ The month-specific fixed effects capture the average of a given labor market outcome for the control group in the specified month.

${ }^{10}$ Each of the controls is measured as a categorical variable with two or more categories. In the regressions we use sets of dummy variables to represent the categories of the control variables. The controls with more than two categories are age (nine categories), race (four categories), educational attainment (five categories), marital status (three categories), and number of children (four categories).

${ }^{11}$ These estimates are for persons age 16 and older. When the sample is restricted to persons age 25 to 64 , the estimated impacts of Katrina increase somewhat for most outcomes. The magnitude of these impacts as a percentage of the means is similar for the age-restricted sample and the full sample. A similar finding was observed in the comparison of returnees and non-returnees when the sample was restricted to persons age 25 to 64 .
} 
Treat $_{i t} \times$ Post $_{i t} \times$ Time $_{t}$, indicates whether the Katrina effect increases or decreases over time.

Estimates of this coefficient, shown in column (4) of Table 2, indicate that the Katrina effects on labor market outcomes decreased over time. This is consistent with some aspects of the Katrina impact being temporary (e.g., job loss, health shock, damage). In an enriched specification with month dummies replacing the linear time trend, monthly estimates of the Katrina effect show a declining pattern over time and the estimates for the later months are substantially smaller than the estimates for the earlier months of the post-Katrina period (Appendix Table 2).

An examination of the earnings and hours of all individuals (workers and non-workers) indicates that Katrina reduced hours worked by 2.1 hours. Consistent with the trend observed for employment, the coefficient on the Treat ${ }_{i t} \times$ Post $_{i t} \times$ Time $_{t}$ variable indicates that the effect of Katrina on hours worked decreased over time. When the analysis is restricted to just those who were employed, the coefficient estimates indicate that evacuees worked an average of 1.5 more hours per week and earned approximately $\$ 52$ more per week after the storm. The larger number of hours worked and higher earnings for evacuees who were employed after the storm could reflect either a direct effect of Katrina on hours/earnings (e.g., through an increase in demand for evacuees' services) or that the employment effects of Katrina were greater for those with lower hours/earnings prior to Katrina.

\section{Comparing Returnees and Non-Returnees}

The estimates in Table 1 indicate considerable differences between evacuees who returned to their pre-Katrina areas and those who did not, with non-returnees faring significantly worse in the labor market. These differences raise questions about the factors that have influenced these evacuees' labor market experiences. Are the differences the result of 
differences in observable characteristics? ${ }^{12}$ Alternatively, are the differences in labor market outcomes the result of hurricane damage being greater for non-returnees than returnees, and in turn are returnees on average better able to resume work with relatively little interruption, while non-returnees are forced to start over? Or are non-returnees a "negatively selected" group of evacuees who had poor labor market outcomes before Katrina, even controlling for their observable characteristics? We explore these questions in two steps. First, we examine differences between returning and non-returning evacuees using a regression framework to account for differences in individual and family characteristics between groups. Second, we relate labor market outcomes to measures of the amount of hurricane damage individuals potentially experienced.

The framework we use for the first step is similar to equation (1) in some respects but it is different in that we rely exclusively on post-Katrina data. We define $R_{i t}$ as a dummy variable for whether evacuees returned to their pre-Katrina county and estimate regressions of the form:

$$
Y_{i t}=\alpha_{t}+\theta X_{i t}+\beta_{r} R_{i t}+\varepsilon_{i t},
$$

where $X_{i t}$ is the same vector of characteristics used in equation (1). The coefficient $\beta_{r}$ captures the magnitude of differences between returnees and non-returnees with similar observable characteristics. Since returning depends in part on the decisions of the evacuees themselves, our interpretation of $\beta_{r}$ is descriptive rather than directly causal.

A comparison of the estimates in columns (2) and (3) of Table 3 indicates that differences in individual and family characteristics explain about 25 percent of the difference in the unemployment rate between those who returned and those who did not and about 40 percent of the difference in earnings when those who are not working are included with a report of zero

\footnotetext{
${ }^{12}$ The percent of evacuees who returned varies across demographic groups (Groen and Polivka 2007). For example, whites were more likely to return than blacks and older people were more likely to return than younger people.
} 
earnings. Differences in characteristics explain only about 10 percent of the difference in hours worked between those who returned and those who did not and only about 5 percent of the difference in the employment-population ratio; differences in characteristics cannot explain the difference in the labor force participation rate. ${ }^{13}$ These results indicate that while individual and family characteristics can explain some of the different labor market outcomes for those who returned and those who did not, a substantial proportion of the difference cannot be explained by these factors.

We estimate whether the differences between returnees and non-returnees (controlling for individual and family characteristics) changed over the post-Katrina period by adding to equation (2) the interaction between the linear time trend Time ${ }_{t}$ (defined above) and the returning variable. The estimated coefficients on this variable, $R_{i t} \times$ Time $_{t}$, suggest that the differences did not consistently decrease or increase over time (column 4 of Table 3). However, in an enriched specification with month dummies replacing the linear time trend, monthly estimates of the differences between returnees and non-returnees increased over the first half of the post-Katrina period in our data and decreased over the second half (Appendix Table 3). This pattern is consistent with the graphs in Groen and Polivka (2007), which show that returnees recovered relatively more quickly, but that non-returnees began to catch up approximately seven months after the storm struck. Nevertheless, at the conclusion of the period we study, non-returnees continued to lag behind returnees, with a higher unemployment rate and a lower employmentpopulation ratio.

To further explore whether negative selectivity existed and the degree to which evacuees' employment relationships may have been disrupted by the storm, we merge our CPS data with

\footnotetext{
${ }^{13}$ Among those who were employed there are no measurable differences in hours and earnings between returnees and non-returnees, both when controls are included and when controls are not included.
} 
external data on the extent of hurricane-related housing damage at the county level. Using data from FEMA on damages to real property and personal property not covered by insurance, we construct three variables representing the percent of housing units in each evacuee's county of origin that experienced minor damage, major damage, or severe damage. ${ }^{14}$ Table 4 reports averages of these percentages separately for returnees and non-returnees in our CPS data. These averages strongly suggest that non-returnees experienced greater housing damage. Among nonreturnees, the average percentage of housing units with severe damage is 29.2 percent, compared to 6.3 percent among returnees. Since job displacement was presumably correlated geographically with housing damage, it is likely that non-returnees also experienced greater job displacement.

We examine the relationship between housing damage and labor market outcomes by estimating regressions of the form:

$$
Y_{i t}=\alpha_{t}+\theta X_{i t}+\beta_{1} \text { Damage }_{i t}+\beta_{2}\left(\text { Damage }_{i t} \times \text { Post }_{i t}\right)+\varepsilon_{i t},
$$

where Damage ${ }_{i t}$ is a measure of the degree of housing damage in the evacuee's county of origin.

We estimate these regressions on the sample of all evacuees and residents of Katrina-affected areas prior to Katrina. Pre-Katrina data are included in the analysis to account for the possibility that the damage variable reflects unobservable characteristics that matter in the labor market. (The damage variable is assigned to the pre-Katrina data based on an individual's county of residence at the time of the CPS interview.) The coefficient $\beta_{2}$ is the parameter of interest

\footnotetext{
${ }^{14}$ U.S. Department of Housing and Urban Development (HUD), Office of Policy Development and Research, "Current Housing Unit Damage Estimates: Hurricanes Katrina, Rita, and Wilma," February 12, 2006. The estimates of damage to real property and personal property were based on direct inspection of housing units to determine eligibility for FEMA housing assistance. Analysts at HUD categorized the amounts of damage not covered by insurance into three categories: minor damage (less than $\$ 5,200$ ), major damage (between $\$ 5,200$ and $\$ 30,000$ ), and severe damage (greater than or equal to $\$ 30,000$ ). We divided the number of housing units in each category by the total number of housing units in a county (according to the 2000 Census) to compute the percentage of housing units in the county that were in each damage category.
} 
because it captures the additional correlation between damage and labor market outcomes for evacuees relative to pre-Katrina residents of affected areas.

We consider three measures of housing damage and include these measures in separate specifications: the percent with severe damage, the percent with severe or major damage, and the percent with severe, major, or minor damage. Since the mechanisms underlying a relationship between damage and labor market outcomes might be somewhat different for returnees and nonreturnees, we vary the sample of evacuees used in these regressions, first using all evacuees and then using only returnees or non-returnees. Among all evacuees, housing damage has a strong negative effect on labor market outcomes (Table 5). For example, a 10 percentage-point increase in the percent with severe damage is associated with a 5.2 percentage-point increase in the unemployment rate and a 3.4 percentage point decrease in the employment-population ratio. Furthermore, the pattern of estimates across specifications of the damage variable indicates that severe damage matters more than major or minor damage.

We interpret these effects of housing damage as reflecting both the impact of job displacement caused by Katrina and the ability of evacuees to find jobs in the Katrina-affected region during the recovery period, with second aspect mattering primarily for returnees. ${ }^{15} \mathrm{~A}$ higher level of damage for returnees could also be associated with them devoting time and resources to rebuilding their homes rather than working in the labor market. Regressions estimated separately for returnees and non-returnees indicate that the extent of damage matters for both groups. The impact of damage on the employment-population ratio is larger among returnees but the impact of damage on the unemployment rate is larger among non-returnees. Taken together, the results in Table 4 and Table 5 imply that the greater level of damage among

\footnotetext{
${ }^{15}$ For evacuees who did not evacuate until after Katrina struck, these effects might also represent the direct effect of Katrina on the health and well-being of evacuees.
} 
non-returnees can account for about half of the differences in labor market outcomes between returnees and non-returnees after controlling for individual and family characteristics. ${ }^{16}$

The impact of damage on labor market outcomes among non-returnees also provides some evidence on the extent to which non-returnees are a "negatively selected" group of evacuees. If such selection were present, we expect that as the level of damage increases, the pool of non-returnees would involve less selection and average outcomes would improve. On the contrary, our estimates suggest the opposite: as damage increased, the outcomes of nonreturnees worsened, mainly through higher unemployment. We interpret this as evidence that non-returnees have fared much worse in the labor market primarily because they probably experienced greater job displacement as evidenced by their origins in areas with more physical damage, rather than because of negative selection.

\section{Conclusions}

CPS data collected after Hurricane Katrina reveal large differences in labor market outcomes between evacuees and non-evacuees. These differences reflect a combination of a causal effect of Katrina on evacuees and pre-Katrina differences between evacuees and nonevacuees. Using a difference-in-differences strategy to isolate the causal effect of Katrina, we estimate that Katrina had substantial effects on the labor market outcomes of evacuees over the 13-month period following Katrina. However, our estimates suggest that the effects of Katrina diminished substantially over time as evacuees recovered from the hurricane and adjusted to new economic and social conditions.

\footnotetext{
${ }^{16}$ Differences in damage can explain 63 percent of the difference between groups in the unemployment rate, 42 percent of the difference in the employment-population ratio, and 20 percent of the labor force participation rate. The difference between returnees and non-returnees in the average percent of housing units with severe damage is 6.3-29.2 =-22.9 (Table 4). Thus, expected differences in labor market outcomes between returnees and nonreturnees, based on the level of severe damage, are the product of (-22.9) and the estimated coefficients on the variable for severe damage for the sample of all evacuees (Table 5). These expected differences can be compared to the estimates in column (3) of Table 3.
} 
Among evacuees, those who did not return to their pre-Katrina areas have fared much worse in the labor market than have those who returned. Differences in individual and family characteristics account for some of the differences in outcomes between returnees and nonreturnees. However, we present evidence that non-returnees have fared much worse in the labor market primarily because they came from areas that experienced greater housing damage due to the storm and thus were more likely to be displaced from their jobs. Evacuees who did not return to the areas they resided in prior to the storm continued to suffer in the labor market compared to evacuees who returned and also compared to non-evacuees. 


\section{References}

Brown, Sharon P., and Patrick Carey. 2006. "Conducting the Mass Layoff Statistics Program: Response and Findings." Monthly Labor Review, 129(8): 70-75.

Cahoon, Lawrence S., Diane E. Herz, Richard C. Ning, Anne E. Polivka, Maria E. Reed, Edwin L. Robison, and Gregory D. Weyland. 2006. "The Current Population Survey Response to Hurricane Katrina.” Monthly Labor Review, 129(8): 40-51.

Groen, Jeffrey A., and Anne E. Polivka. 2007. "Hurricane Katrina Evacuees: Who They Are, Where They Are, and How They Are Faring." Forthcoming in Monthly Labor Review.

Kletzer, Lori G. 1998. “Job Displacement.” Journal of Economic Perspectives, 12(1): 115-36.

U.S. Bureau of Labor Statistics, Office of Employment and Unemployment Statistics. 2006. "The Labor Market Impact of Hurricane Katrina: An Overview." Monthly Labor Review, 129(8): 3-10.

Vigdor, Jacob L. 2007. "The Katrina Effect: Was There a Bright Side to the Evacuation of Greater New Orleans?” B.E. Journal of Economic Analysis \& Policy, 7(1): Article 64. 
Table 1.

Labor Market Outcomes of Evacuees and Non-Evacuees, October 2005 - October 2006

\begin{tabular}{lrrrr}
\hline \hline & & & \multicolumn{2}{c}{ Evacuees } \\
\cline { 4 - 5 } & $\begin{array}{r}\text { Non- } \\
\text { Evacuees }\end{array}$ & Evacuees & Returnees & $\begin{array}{r}\text { Non- } \\
\text { Returnees }\end{array}$ \\
\hline Labor force participation rate & 66.2 & 58.8 & 60.9 & 53.4 \\
Employment-population ratio & 63.1 & 51.7 & 57.3 & 37.1 \\
Unemployment rate & 4.7 & 12.1 & 6.0 & 30.6 \\
Average hours in prior week & 23.9 & 19.9 & 22.2 & 13.9 \\
Hours (workers only) & 38.4 & 39.6 & 39.6 & 39.8 \\
Average usual weekly earnings & $\$ 464$ & $\$ 342$ & $\$ 377$ & $\$ 252$ \\
Earnings (workers only) & $\$ 770$ & $\$ 685$ & $\$ 683$ & $\$ 695$ \\
Number of observations & $1,366,831$ & 6,550 & 4,769 & 1,753 \\
\hline
\end{tabular}

Notes: Hours and earnings are based on a person's main job. Earnings are expressed in October 2006 dollars. 
Table 2.

Effect of Hurricane Katrina on Labor Market Outcomes of Evacuees

\begin{tabular}{|c|c|c|c|c|c|}
\hline & Mean & $\begin{array}{l}(2) \\
\\
\text { Treat } \\
\times \text { Post } \\
\end{array}$ & $\begin{array}{l}\text { Treat } \\
\times \text { Post }\end{array}$ & $\begin{array}{c}(4) \\
\text { Treat } \\
\times \text { Post } \\
\times \text { Time }\end{array}$ & (5) \\
\hline \multicolumn{6}{|l|}{ Independent variables } \\
\hline Treat, Treat $\times$ Post & & $\mathrm{x}$ & $\mathrm{x}$ & $\mathrm{x}$ & \\
\hline Month fixed effects & & $\mathrm{x}$ & $\mathrm{x}$ & $\mathrm{x}$ & \\
\hline Individual and family characteristics & & & $\mathrm{x}$ & $\mathrm{x}$ & \\
\hline Treat $\times$ Post $\times$ Time & & & & $\mathrm{x}$ & \\
\hline \multicolumn{6}{|l|}{ Dependent variable } \\
\hline Labor force participation rate & 66.06 & $\begin{array}{l}-3.70 \\
(1.23)\end{array}$ & $\begin{array}{l}-3.48 \\
(1.06)\end{array}$ & $\begin{array}{c}0.47 \\
(0.21)\end{array}$ & $2,650,914$ \\
\hline Employment-population ratio & 62.79 & $\begin{array}{l}-7.44 \\
(1.25)\end{array}$ & $\begin{array}{l}-7.05 \\
(1.11)\end{array}$ & $\begin{array}{c}0.71 \\
(0.22)\end{array}$ & $2,650,914$ \\
\hline Unemployment rate & 4.95 & $\begin{array}{c}6.67 \\
(0.90)\end{array}$ & $\begin{array}{c}6.28 \\
(0.86)\end{array}$ & $\begin{array}{l}-0.54 \\
(0.20)\end{array}$ & $1,761,613$ \\
\hline Hours in prior week & 23.73 & $\begin{array}{l}-2.45 \\
(0.55)\end{array}$ & $\begin{array}{l}-2.05 \\
(0.47)\end{array}$ & $\begin{array}{c}0.23 \\
(0.10)\end{array}$ & $2,582,741$ \\
\hline Hours (workers only) & 38.37 & $\begin{array}{c}1.14 \\
(0.40)\end{array}$ & $\begin{array}{c}1.48 \\
(0.37)\end{array}$ & $\begin{array}{l}-0.13 \\
(0.09)\end{array}$ & $1,610,661$ \\
\hline Usual weekly earnings & 461.22 & $\begin{array}{l}-24.74 \\
(16.78)\end{array}$ & $\begin{array}{l}-11.56 \\
(15.06)\end{array}$ & $\begin{array}{c}7.40 \\
(3.94)\end{array}$ & 618,077 \\
\hline Earnings (workers only) & 768.95 & $\begin{array}{c}29.70 \\
(26.61)\end{array}$ & $\begin{array}{c}52.06 \\
(23.64)\end{array}$ & $\begin{array}{c}2.13 \\
(6.22)\end{array}$ & 372,308 \\
\hline
\end{tabular}

Notes: The numbers reported in columns (2)-(4) are estimated coefficients associated with the variable listed in the column heading. Standard errors in parentheses account for the clustering of individual observations. Regressions are estimated as linear models and weighted using CPS sampling weights. For the first three dependent variables, the means, coefficients, and standard errors have been multiplied by 100 and thus should be interpreted as percentage points. 
Table 3.

Differences in Labor Market Outcomes between Returnees and Non-Returnees

\begin{tabular}{|c|c|c|c|c|c|}
\hline & $\begin{array}{c}(1) \\
\text { Mean } \\
\end{array}$ & Return & Return & $\begin{array}{c}(4) \\
\text { Return } \\
\times \text { Time }\end{array}$ & (5) \\
\hline \multicolumn{6}{|l|}{ Independent variables } \\
\hline Return & & $\mathrm{x}$ & $\mathrm{x}$ & $\mathrm{x}$ & \\
\hline Month fixed effects & & $\mathrm{x}$ & $\mathrm{x}$ & $\mathrm{x}$ & \\
\hline Individual and family characteristics & & & $\mathrm{x}$ & $\mathrm{x}$ & \\
\hline Time, Return $\times$ Time & & & & $\mathrm{x}$ & \\
\hline Housing damage & & & & & \\
\hline \multicolumn{6}{|l|}{ Dependent variable } \\
\hline Labor force participation rate & 58.99 & $\begin{array}{c}6.79 \\
(2.51)\end{array}$ & $\begin{array}{c}9.37 \\
(2.28)\end{array}$ & $\begin{array}{c}0.31 \\
(0.50)\end{array}$ & 6,429 \\
\hline Employment-population ratio & 51.85 & $\begin{array}{l}19.86 \\
(2.48)\end{array}$ & $\begin{array}{l}18.58 \\
(2.32)\end{array}$ & $\begin{array}{c}0.19 \\
(0.52)\end{array}$ & 6,429 \\
\hline Unemployment rate & 12.10 & $\begin{array}{l}-25.06 \\
(2.69)\end{array}$ & $\begin{array}{l}-18.81 \\
(2.29)\end{array}$ & $\begin{array}{c}0.44 \\
(0.59)\end{array}$ & 3,764 \\
\hline Hours in prior week & 20.00 & $\begin{array}{c}8.20 \\
(1.09)\end{array}$ & $\begin{array}{c}7.26 \\
(1.02)\end{array}$ & $\begin{array}{l}-0.08 \\
(0.24)\end{array}$ & 6,243 \\
\hline Hours (workers only) & 39.61 & $\begin{array}{l}-0.11 \\
(0.97)\end{array}$ & $\begin{array}{c}0.04 \\
(0.85)\end{array}$ & $\begin{array}{l}-0.14 \\
(0.22)\end{array}$ & 3,159 \\
\hline Usual weekly earnings & 343.25 & $\begin{array}{l}113.71 \\
(35.70)\end{array}$ & $\begin{array}{c}64.49 \\
(41.84)\end{array}$ & $\begin{array}{c}10.24 \\
(10.52)\end{array}$ & 1,520 \\
\hline Earnings (workers only) & 686.10 & $\begin{array}{l}-10.02 \\
(75.47)\end{array}$ & $\begin{array}{c}-102.10 \\
(78.44)\end{array}$ & $\begin{array}{c}-7.42 \\
(21.49)\end{array}$ & 760 \\
\hline
\end{tabular}

Notes: The numbers reported in columns (2)-(4) are estimated coefficients associated with the variable listed in the column heading. Standard errors in parentheses account for the clustering of individual observations. Regressions are estimated as linear models and weighted using CPS sampling weights. For the first three dependent variables, the means, coefficients, and standard errors have been multiplied by 100 and thus should be interpreted as percentage points. 
Table 4.

Differences in Housing Damage between Returnees and Non-Returnees

\begin{tabular}{lrrr}
\hline \hline & $\begin{array}{r}\text { All } \\
\text { Evacuees }\end{array}$ & $\begin{array}{r}\text { Non- } \\
\text { Returnees }\end{array}$ & $\begin{array}{r}\text { Returnees } \\
\hline \text { Severe damage }\end{array}$ \\
Major damage & 12.4 & 6.3 & 29.2 \\
Minor damage & 30.4 & 13.8 & 15.9 \\
No damage & 42.7 & 34.0 & 21.0 \\
Severe or major & 26.7 & 25.9 & 33.8 \\
Severe, major, or minor & 57.3 & 54.1 & 45.1 \\
Number of observations & 6,429 & 4,769 & 66.2 \\
\hline
\end{tabular}

Note: The numbers in the table are averages of the percent of housing units in the evacuee's county of origin that experienced a given level of damage. 
Table 5.

Relationship between Housing Damage and Labor Market Outcomes

\begin{tabular}{|c|c|c|c|c|c|c|c|}
\hline & LFPR $^{\mathrm{a}}$ & $\mathrm{EPR}^{\mathrm{b}}$ & $\mathrm{UR}^{\mathrm{c}}$ & $\begin{array}{c}\text { Weekly } \\
\text { hours }\end{array}$ & $\begin{array}{c}\text { Hours } \\
\text { (workers) }\end{array}$ & $\begin{array}{l}\text { Weekly } \\
\text { earnings }\end{array}$ & $\begin{array}{c}\text { Earnings } \\
\text { (workers) }\end{array}$ \\
\hline \multicolumn{8}{|l|}{ All evacuees } \\
\hline \multirow[t]{2}{*}{ Severe } & -0.08 & -0.34 & 0.52 & -0.15 & -0.03 & -2.99 & -1.87 \\
\hline & $(0.04)$ & $(0.07)$ & $(0.11)$ & $(0.03)$ & $(0.02)$ & $(0.84)$ & $(1.21)$ \\
\hline \multirow[t]{2}{*}{ Severe or major } & -0.06 & -0.24 & 0.35 & -0.11 & -0.03 & -2.01 & -0.74 \\
\hline & $(0.05)$ & $(0.09)$ & $(0.13)$ & $(0.04)$ & $(0.02)$ & $(0.91)$ & $(1.16)$ \\
\hline \multirow[t]{2}{*}{ Severe, major, or minor } & -0.03 & -0.16 & 0.23 & -0.10 & -0.06 & -1.75 & -1.20 \\
\hline & $(0.08)$ & $(0.12)$ & $(0.15)$ & $(0.05)$ & $(0.03)$ & $(1.29)$ & $(1.51)$ \\
\hline Mean & 61.60 & 57.09 & 7.32 & 21.66 & 38.61 & 358.26 & 662.06 \\
\hline $\mathrm{N}$ & 28,553 & 28,553 & 17,316 & 27,877 & 15,446 & 6,814 & 3,628 \\
\hline \multicolumn{8}{|l|}{ Returnees } \\
\hline \multirow{2}{*}{ Severe } & -0.11 & -0.17 & 0.15 & -0.08 & -0.02 & -4.38 & -4.34 \\
\hline & $(0.06)$ & $(0.05)$ & $(0.03)$ & $(0.02)$ & $(0.02)$ & $(0.60)$ & $(1.23)$ \\
\hline \multirow[t]{2}{*}{ Severe or major } & -0.02 & -0.07 & 0.09 & -0.05 & -0.04 & -2.18 & -1.49 \\
\hline & $(0.08)$ & $(0.08)$ & $(0.03)$ & $(0.03)$ & $(0.03)$ & $(1.15)$ & $(1.56)$ \\
\hline \multirow[t]{2}{*}{ Severe, major, or minor } & 0.03 & 0.00 & 0.04 & -0.03 & -0.06 & -1.60 & -2.07 \\
\hline & $(0.09)$ & $(0.09)$ & $(0.04)$ & $(0.03)$ & $(0.03)$ & $(1.26)$ & $(1.61)$ \\
\hline Mean & 62.12 & 58.42 & 5.95 & 22.16 & 38.57 & 365.85 & 660.32 \\
\hline $\mathrm{N}$ & 26,893 & 26,893 & 16,428 & 26,271 & 14,857 & 6,410 & 3,475 \\
\hline \multicolumn{8}{|l|}{ Non-returnees } \\
\hline \multirow[t]{2}{*}{ Severe } & 0.16 & -0.09 & 0.47 & -0.06 & -0.05 & -1.18 & -3.98 \\
\hline & $(0.07)$ & $(0.11)$ & $(0.21)$ & $(0.05)$ & $(0.03)$ & $(1.42)$ & $(2.27)$ \\
\hline \multirow[t]{2}{*}{ Severe or major } & 0.09 & -0.08 & 0.34 & -0.05 & -0.04 & -0.78 & -2.28 \\
\hline & $(0.08)$ & $(0.10)$ & $(0.20)$ & $(0.05)$ & $(0.03)$ & (1.09) & $(1.91)$ \\
\hline \multirow[t]{2}{*}{ Severe, major, or minor } & 0.04 & -0.16 & 0.43 & -0.10 & -0.07 & -0.10 & -0.13 \\
\hline & $(0.13)$ & $(0.15)$ & $(0.23)$ & $(0.07)$ & $(0.05)$ & $(0.95)$ & $(2.33)$ \\
\hline Mean & 61.75 & 57.06 & 7.59 & 21.54 & 38.42 & 354.14 & 657.40 \\
\hline $\mathrm{N}$ & 23,784 & 23,784 & 14,440 & 23,240 & 12,876 & 5,698 & 3,021 \\
\hline
\end{tabular}

Notes: The numbers reported in the table are estimated coefficients on Damage $\times$ Post variable and associated standard errors (in parentheses) that account for the clustering of observations at the county level. Each cell is based on a separate regression involving the dependent variable listed in the column heading. Regressions are estimated as linear models and weighted using CPS sampling weights. For the first three dependent variables, the means, coefficients, and standard errors have been multiplied by 100 and thus should be interpreted as percentage points.

${ }^{a}$ Labor Force Participation Rate

${ }^{\mathrm{b}}$ Employment-Population Ratio

${ }^{\mathrm{c}}$ Unemployment Rate 
Appendix Table 1.

Treatment and Control Groups Before and After Hurricane Katrina

\begin{tabular}{|c|c|c|c|c|}
\hline Variable & $\begin{array}{r}\text { Treatment } \\
\text { Pre }\end{array}$ & $\begin{array}{r}\text { Treatment } \\
\text { Post } \\
\end{array}$ & $\begin{array}{r}\text { Control } \\
\text { Pre }\end{array}$ & $\begin{array}{r}\text { Control } \\
\text { Post }\end{array}$ \\
\hline Age 16 to 19 & 7.5 & 9.2 & 7.2 & 7.3 \\
\hline Age 20 to 24 & 10.4 & 11.0 & 9.0 & 8.9 \\
\hline Age 25 to 34 & 17.5 & 17.1 & 17.3 & 17.2 \\
\hline Age 35 to 44 & 18.0 & 17.2 & 19.2 & 18.8 \\
\hline Age 45 to 54 & 18.2 & 17.7 & 18.6 & 18.7 \\
\hline Age 55 to 69 & 7.4 & 8.0 & 7.5 & 7.8 \\
\hline Age 60 to 64 & 6.0 & 5.7 & 5.7 & 5.8 \\
\hline Age 65 to 74 & 8.1 & 8.4 & 8.1 & 8.2 \\
\hline Age $75+$ & 6.9 & 5.7 & 7.4 & 7.4 \\
\hline White & 65.4 & 63.3 & 82.0 & 81.6 \\
\hline Black & 32.5 & 32.7 & 11.2 & 11.6 \\
\hline Asian & 1.1 & 2.6 & 4.4 & 4.4 \\
\hline Other race & 1.1 & 1.4 & 2.4 & 2.4 \\
\hline Hispanic & 1.7 & 3.6 & 13.0 & 13.2 \\
\hline Male & 46.7 & 45.5 & 48.3 & 48.3 \\
\hline Less than high school & 21.9 & 21.7 & 18.6 & 18.2 \\
\hline High school & 34.1 & 34.1 & 30.7 & 30.5 \\
\hline Some college & 24.4 & 26.6 & 26.2 & 26.4 \\
\hline College & 13.3 & 12.4 & 16.3 & 16.5 \\
\hline Graduate degree & 6.3 & 5.2 & 8.2 & 8.3 \\
\hline Married & 51.7 & 46.2 & 54.7 & 54.3 \\
\hline Was married & 19.2 & 20.8 & 17.9 & 18.1 \\
\hline Never married & 29.0 & 33.0 & 27.3 & 27.7 \\
\hline 0 children & 70.7 & 71.8 & 70.8 & 71.2 \\
\hline 1 child & 13.4 & 13.5 & 12.0 & 12.0 \\
\hline 2 children & 10.5 & 8.6 & 11.2 & 11.0 \\
\hline $3+$ children & 5.4 & 6.1 & 6.0 & 5.9 \\
\hline Live in MSA & 71.6 & 84.1 & 83.6 & 83.6 \\
\hline Foreign born & 3.0 & 4.6 & 14.6 & 14.8 \\
\hline Veteran of military & 9.2 & 9.8 & 9.9 & 9.9 \\
\hline Labor force participation rate & 62.4 & 58.8 & 66.1 & 66.2 \\
\hline Employment-population ratio & 58.7 & 51.7 & 62.6 & 63.1 \\
\hline Unemployment rate & 5.9 & 12.1 & 5.2 & 4.7 \\
\hline Hours in prior week & 22.2 & 19.9 & 23.6 & 23.9 \\
\hline Hours (workers only) & 38.4 & 39.6 & 38.3 & 38.4 \\
\hline Usual weekly earnings & $\$ 363$ & $\$ 342$ & $\$ 461$ & $\$ 464$ \\
\hline Earnings (workers only) & $\$ 655$ & $\$ 685$ & $\$ 770$ & $\$ 770$ \\
\hline $\mathrm{N}$ & 22,124 & 6,550 & $1,255,409$ & $1,366,831$ \\
\hline
\end{tabular}

Note: Means weighted by CPS sampling weights. For all variables except hours and earnings, the means have been multiplied by 100 and thus should be interpreted as percentage points. 
Appendix Table 2.

Month-Specific Estimates of the Effect of Hurricane Katrina on Evacuees

\begin{tabular}{|c|c|c|c|c|c|c|c|}
\hline Month & $\mathrm{LFPR}^{\mathrm{a}}$ & $\mathrm{EPR}^{\mathrm{b}}$ & $\mathrm{UR}^{\mathrm{c}}$ & $\begin{array}{l}\text { Weekly } \\
\text { hours }\end{array}$ & $\begin{array}{c}\text { Hours } \\
\text { (workers) }\end{array}$ & $\begin{array}{l}\text { Weekly } \\
\text { earnings }\end{array}$ & $\begin{array}{l}\text { Earnings } \\
\text { (workers) }\end{array}$ \\
\hline \multirow[t]{2}{*}{ October 2005} & -8.03 & -14.59 & 13.48 & -5.04 & 3.39 & 5.20 & 73.42 \\
\hline & $(2.57)$ & $(2.61)$ & $(2.91)$ & $(1.23)$ & $(1.29)$ & $(50.87)$ & $(61.50)$ \\
\hline \multirow[t]{2}{*}{ November 2005} & -5.92 & -11.11 & 9.72 & -3.35 & 2.13 & -98.57 & 80.38 \\
\hline & $(2.19)$ & $(2.24)$ & $(2.31)$ & $(0.97)$ & $(0.89)$ & $(61.71)$ & $(120.08)$ \\
\hline \multirow[t]{2}{*}{ December 2005} & -4.93 & -7.91 & 5.60 & -2.02 & 2.25 & -36.70 & 21.77 \\
\hline & (2.09) & $(2.14)$ & $(1.91)$ & $(0.95)$ & $(0.85)$ & $(32.57)$ & $(50.48)$ \\
\hline \multirow[t]{2}{*}{ January 2006} & -4.46 & -8.90 & 8.09 & -2.77 & 1.21 & -89.33 & -39.67 \\
\hline & $(2.06)$ & (2.09) & $(2.14)$ & $(0.88)$ & $(0.77)$ & $(38.03)$ & $(50.31)$ \\
\hline \multirow[t]{2}{*}{ February 2006} & -4.45 & -6.76 & 4.33 & -1.30 & 2.52 & 59.39 & 146.67 \\
\hline & $(2.11)$ & $(2.14)$ & $(1.86)$ & $(0.92)$ & $(0.78)$ & $(55.96)$ & $(83.31)$ \\
\hline \multirow[t]{2}{*}{ March 2006} & -5.07 & -8.80 & 7.07 & -2.40 & 1.52 & -19.63 & -4.82 \\
\hline & $(2.13)$ & $(2.17)$ & $(2.19)$ & $(0.91)$ & $(0.68)$ & $(38.27)$ & $(46.31)$ \\
\hline \multirow[t]{2}{*}{ April 2006} & -3.98 & -8.98 & 8.78 & -2.90 & 1.34 & -78.98 & 19.28 \\
\hline & $(2.17)$ & $(2.25)$ & $(2.35)$ & $(0.92)$ & $(0.73)$ & $(37.95)$ & $(53.70)$ \\
\hline \multirow[t]{2}{*}{ May 2006} & -1.73 & -6.09 & 6.80 & -1.87 & 1.03 & -75.07 & -54.31 \\
\hline & (1.98) & $(2.07)$ & $(1.98)$ & $(0.87)$ & $(0.71)$ & $(34.00)$ & $(46.46)$ \\
\hline \multirow[t]{2}{*}{ June 2006} & -0.66 & -4.42 & 5.74 & -1.79 & -0.04 & 59.11 & 109.27 \\
\hline & $(1.86)$ & (1.99) & $(1.85)$ & $(0.84)$ & $(0.74)$ & $(43.54)$ & $(66.01)$ \\
\hline \multirow[t]{2}{*}{ July 2006} & -2.23 & -4.42 & 3.65 & -1.55 & 0.78 & -11.96 & 24.65 \\
\hline & (1.91) & (1.99) & $(1.68)$ & $(0.89)$ & $(0.78)$ & $(37.90)$ & $(50.04)$ \\
\hline \multirow[t]{2}{*}{ August 2006} & -1.20 & -3.93 & 4.54 & -0.44 & 1.98 & 76.11 & 196.09 \\
\hline & $(1.86)$ & (1.99) & $(1.74)$ & $(0.90)$ & $(0.80)$ & (76.59) & $(129.05)$ \\
\hline \multirow[t]{2}{*}{ September 2006} & -2.38 & -3.77 & 2.67 & -0.72 & 1.28 & 56.00 & 55.37 \\
\hline & (1.95) & $(2.04)$ & $(1.66)$ & $(0.92)$ & $(0.87)$ & $(48.60)$ & $(75.79)$ \\
\hline \multirow[t]{2}{*}{ October 2006} & -1.91 & -4.44 & 4.11 & -1.45 & 0.95 & -29.87 & -16.68 \\
\hline & $(2.15)$ & $(2.25)$ & $(1.92)$ & $(1.00)$ & $(0.91)$ & $(48.22)$ & $(71.31)$ \\
\hline First 7 months (a1) & -5.26 & -9.58 & 8.15 & -2.83 & 2.05 & -36.95 & 42.43 \\
\hline Last 6 months (a2) & -1.69 & -4.51 & 4.59 & -1.30 & 1.00 & 12.39 & 52.40 \\
\hline $\mathrm{H}_{\mathrm{o}}(\mathrm{a} 1=\mathrm{a} 2): \mathrm{F}$ stat. & 5.15 & 9.42 & 5.97 & 4.30 & 2.93 & 3.48 & 0.06 \\
\hline $\mathrm{H}_{\mathrm{o}}(\mathrm{a} 1=\mathrm{a} 2): \mathrm{p}$-value & 0.02 & 0.00 & 0.01 & 0.04 & 0.09 & 0.06 & 0.81 \\
\hline
\end{tabular}

Notes: The numbers reported in the table are estimated coefficients associated with the relevant month $\times$ Treat $\times$ Post variable. Standard errors in parentheses account for the clustering of individual observations. Regressions are estimated as linear models and weighted using CPS sampling weights. For the first three dependent variables, the coefficients and standard errors have been multiplied by 100 and thus should be interpreted as percentage points.

${ }^{a}$ Labor Force Participation Rate

${ }^{\mathrm{b}}$ Employment-Population Ratio

${ }^{c}$ Unemployment Rate 
Appendix Table 3.

Month-Specific Estimates of the Difference between Returnees and Non-Returnees

\begin{tabular}{|c|c|c|c|c|c|c|c|}
\hline Month & $\mathrm{LFPR}^{\mathrm{a}}$ & $\mathrm{EPR}^{\mathrm{b}}$ & $\mathrm{UR}^{\mathrm{c}}$ & $\begin{array}{c}\text { Weekly } \\
\text { hours }\end{array}$ & $\begin{array}{c}\text { Hours } \\
\text { (workers) }\end{array}$ & $\begin{array}{l}\text { Weekly } \\
\text { earnings }\end{array}$ & $\begin{array}{l}\text { Earnings } \\
\text { (workers) }\end{array}$ \\
\hline October 2005 & $\begin{array}{c}1.15 \\
(5.25)\end{array}$ & $\begin{array}{l}12.03 \\
(5.13)\end{array}$ & $\begin{array}{l}-22.26 \\
(6.40)\end{array}$ & $\begin{array}{c}7.41 \\
(2.40)\end{array}$ & $\begin{array}{c}2.52 \\
(3.23)\end{array}$ & $\begin{array}{c}156.70 \\
(101.56)\end{array}$ & $\begin{array}{c}160.35 \\
(101.64)\end{array}$ \\
\hline November 2005 & $\begin{array}{c}3.76 \\
(4.88)\end{array}$ & $\begin{array}{l}12.61 \\
(4.78)\end{array}$ & $\begin{array}{l}-18.26 \\
(5.92)\end{array}$ & $\begin{array}{c}4.44 \\
(2.05)\end{array}$ & $\begin{array}{l}-0.43 \\
(1.93)\end{array}$ & $\begin{array}{l}-173.30 \\
(140.50)\end{array}$ & $\begin{array}{l}-420.18 \\
(322.68)\end{array}$ \\
\hline December 2005 & $\begin{array}{c}9.89 \\
(4.83)\end{array}$ & $\begin{array}{l}15.86 \\
(4.76)\end{array}$ & $\begin{array}{r}-13.20 \\
(5.44)\end{array}$ & $\begin{array}{c}6.66 \\
(2.13)\end{array}$ & $\begin{array}{l}-0.03 \\
(2.22)\end{array}$ & $\begin{array}{c}103.93 \\
(75.28)\end{array}$ & $\begin{array}{c}-316.07 \\
(186.52)\end{array}$ \\
\hline January 2006 & $\begin{array}{l}12.26 \\
(4.46)\end{array}$ & $\begin{array}{l}19.74 \\
(4.27)\end{array}$ & $\begin{array}{l}-17.60 \\
(5.47)\end{array}$ & $\begin{array}{c}7.72 \\
(1.78)\end{array}$ & $\begin{array}{c}0.88 \\
(1.79)\end{array}$ & $\begin{array}{c}13.20 \\
(71.74)\end{array}$ & $\begin{array}{c}38.66 \\
(110.32)\end{array}$ \\
\hline February 2006 & $\begin{array}{c}9.70 \\
(4.89)\end{array}$ & $\begin{array}{l}18.48 \\
(4.75)\end{array}$ & $\begin{array}{l}-18.03 \\
(5.32)\end{array}$ & $\begin{array}{c}7.54 \\
(1.95)\end{array}$ & $\begin{array}{c}0.29 \\
(1.73)\end{array}$ & $\begin{array}{c}25.75 \\
(105.72)\end{array}$ & $\begin{array}{c}-60.72 \\
(160.28)\end{array}$ \\
\hline March 2006 & $\begin{array}{l}16.57 \\
(4.97)\end{array}$ & $\begin{array}{l}29.56 \\
(4.43)\end{array}$ & $\begin{array}{l}-30.76 \\
(6.12)\end{array}$ & $\begin{array}{l}11.17 \\
(1.88)\end{array}$ & $\begin{array}{l}-0.22 \\
(1.90)\end{array}$ & $\begin{array}{c}116.81 \\
(98.27)\end{array}$ & $\begin{array}{c}-17.97 \\
(96.24)\end{array}$ \\
\hline April 2006 & $\begin{array}{l}10.97 \\
(5.02)\end{array}$ & $\begin{array}{l}22.92 \\
(4.79)\end{array}$ & $\begin{array}{l}-26.27 \\
(6.59)\end{array}$ & $\begin{array}{c}8.83 \\
(1.97)\end{array}$ & $\begin{array}{c}1.31 \\
(2.51)\end{array}$ & $\begin{array}{c}79.40 \\
(74.68)\end{array}$ & $\begin{array}{c}-151.64 \\
(158.83)\end{array}$ \\
\hline May 2006 & $\begin{array}{l}11.62 \\
(4.84)\end{array}$ & $\begin{array}{l}22.43 \\
(4.80)\end{array}$ & $\begin{array}{l}-20.44 \\
(5.79)\end{array}$ & $\begin{array}{c}8.95 \\
(1.96)\end{array}$ & $\begin{array}{c}0.08 \\
(1.70)\end{array}$ & $\begin{array}{c}94.72 \\
(75.11)\end{array}$ & $\begin{array}{c}-90.84 \\
(133.79)\end{array}$ \\
\hline June 2006 & $\begin{array}{c}8.08 \\
(4.77)\end{array}$ & $\begin{array}{l}20.24 \\
(4.88)\end{array}$ & $\begin{array}{l}-21.88 \\
(5.80)\end{array}$ & $\begin{array}{c}7.47 \\
(2.12)\end{array}$ & $\begin{array}{l}-1.02 \\
(2.61)\end{array}$ & $\begin{array}{l}114.35 \\
(90.78)\end{array}$ & $\begin{array}{c}-160.30 \\
(123.07)\end{array}$ \\
\hline July 2006 & $\begin{array}{c}7.73 \\
(4.72)\end{array}$ & $\begin{array}{l}18.81 \\
(4.84)\end{array}$ & $\begin{array}{l}-19.54 \\
(5.35)\end{array}$ & $\begin{array}{c}6.88 \\
(2.16)\end{array}$ & $\begin{array}{l}-0.30 \\
(2.13)\end{array}$ & $\begin{array}{l}216.40 \\
(73.61)\end{array}$ & $\begin{array}{l}152.53 \\
(81.57)\end{array}$ \\
\hline August 2006 & $\begin{array}{c}6.23 \\
(4.30)\end{array}$ & $\begin{array}{l}15.31 \\
(4.79)\end{array}$ & $\begin{array}{l}-14.92 \\
(5.31)\end{array}$ & $\begin{array}{c}4.99 \\
(2.20)\end{array}$ & $\begin{array}{l}-0.52 \\
(2.01)\end{array}$ & $\begin{array}{c}12.80 \\
(237.33)\end{array}$ & $\begin{array}{c}-510.43 \\
(486.39)\end{array}$ \\
\hline September 2006 & $\begin{array}{l}10.61 \\
(4.73)\end{array}$ & $\begin{array}{l}15.56 \\
(5.02)\end{array}$ & $\begin{array}{l}-11.61 \\
(5.55)\end{array}$ & $\begin{array}{c}5.80 \\
(2.23)\end{array}$ & $\begin{array}{c}0.16 \\
(1.98)\end{array}$ & $\begin{array}{c}77.14 \\
(92.47)\end{array}$ & $\begin{array}{c}-14.44 \\
(140.53)\end{array}$ \\
\hline October 2006 & $\begin{array}{l}12.10 \\
(5.69)\end{array}$ & $\begin{array}{l}15.92 \\
(5.72)\end{array}$ & $\begin{array}{l}-9.92 \\
(6.26)\end{array}$ & $\begin{array}{c}5.48 \\
(2.58)\end{array}$ & $\begin{array}{l}-1.52 \\
(2.65)\end{array}$ & $\begin{array}{l}126.80 \\
(90.01)\end{array}$ & $\begin{array}{c}-31.81 \\
(140.94)\end{array}$ \\
\hline First 5 months (a1) & 7.35 & 15.74 & -17.87 & 6.75 & 0.64 & 25.26 & -119.59 \\
\hline March 2006 (a2) & 16.57 & 29.56 & -30.76 & 11.17 & -0.22 & 116.81 & -17.97 \\
\hline Last 7 months (a3) & 9.62 & 18.74 & -17.80 & 6.91 & -0.26 & 103.09 & -115.28 \\
\hline $\mathrm{H}_{\mathrm{o}}(\mathrm{a} 1=\mathrm{a} 2): \mathrm{F}$ stat. & 3.39 & 9.16 & 4.04 & 4.86 & 0.17 & 0.67 & 0.64 \\
\hline $\mathrm{H}_{\mathrm{o}}(\mathrm{a} 1=\mathrm{a} 2)$ : $\mathrm{p}$-value & 0.07 & 0.00 & 0.04 & 0.03 & 0.68 & 0.41 & 0.42 \\
\hline $\mathrm{H}_{\mathrm{o}}(\mathrm{a} 2=\mathrm{a} 3): \mathrm{F}$ stat. & 1.85 & 5.45 & 4.24 & 4.44 & 0.00 & 0.01 & 0.51 \\
\hline $\mathrm{H}_{\mathrm{o}}(\mathrm{a} 2=\mathrm{a} 3)$ : $\mathrm{p}$-value & 0.17 & 0.02 & 0.04 & 0.04 & 0.99 & 0.90 & 0.48 \\
\hline
\end{tabular}

Notes: The numbers reported in the table are estimated coefficients associated with the relevant month $\times$ Return variable. Standard errors in parentheses account for the clustering of individual observations. Regressions are estimated as linear models and weighted using CPS sampling weights. For the first three dependent variables, the coefficients and standard errors have been multiplied by 100 and thus should be interpreted as percentage points.

${ }^{a}$ Labor Force Participation Rate; ${ }^{b}$ Employment-Population Ratio; ${ }^{c}$ Unemployment Rate 